ScIDoC

\section{International Journal of Dentistry and Oral Science (IJDOS) ISSN: $2377-8075$}

\title{
Prevalence Of Impacted Teeth In Adult Population
}

Shruthi $\mathrm{M}^{1}$, Hemavathy O.R ${ }^{2 *}$, Murugan Thamaraiselvan ${ }^{3}$

${ }^{1}$ Saveetha Dental College And Hospitals, Saveetha Institute Of Medical and Technical Sciences, Saveetha University, Chennai,600050, India.

${ }^{2}$ Reader, Department of Oral and Maxillofacial Surgery, Saveetha Dental College and Hospitals, Saveetha Institute Of Medical And Technical Sciences, Saveetha University, Chennai, India.

${ }^{3}$ Reader, Department of Periodontics, Saveetha Dental College and Hospitals, Saveetha Institute Of Medical and Technical Science, Saveetha University, Chennai 77, India.

\section{Abstract}

Dental impaction is a frequent phenomenon. Impacted teeth are those teeth that remain unerupted / retained / partially erupted and they differ from the normal arch relationship of the teeth that are present in our mouth. The study aims at estimating the prevalence of impacted teeth in the adult population.This is a retrospective study where patients reported with impacted teeth between June 2019 to march 2020 in Saveetha Dental College and Hospitals was taken and out of which 785 patient records was taken, the investigation was done to relate the impaction of tooth to age and sex.The prevalence of teeth impaction for different age groups was found wherein 15-30 years being the most common age group to exhibit impaction and Male predominance was observed. Incidence of impaction is more common in mandibular third molar (84.1\%). This research focuses on the prevalence of impacted teeth and gives an insight of most common tooth impacted, its predilection and the possible complications of impaction.

Keywords: Impaction; Frequent; Prevalence; Age; Sex; Complications.

\section{Introduction}

Dental impaction is a very frequent problem. The Latin word 'impactus' means an organ/structure which because of an abnormal mechanical condition has been prevented from assuming its normal position which gave to the word impaction. It is prevented by the overlying gums, bone or another tooth [39, 46] The etiology of impaction includes two broad categories- local and systemic factors. Local causes include lack of space, retained deciduous teeth, premature loss of deciduous teeth, ectopic position of tooth bud, obstruction of eruption path, cyst tumour and supernumerary teeth, infection and trauma, abnormalities of jaw and dilaceration. Systemic causes includes prenatal causes like heredity, postnatal causes like rickets, anaemia, congenital syphilis, endocrine dysfunction and malnutrition and rare conditions like cleidocranial dysostosis, oxycephaly, progeria, Achondroplasia and abnormal birth defect.

There are many factors which affect the prevalence of teeth im- paction; they are selected age group, eruption time of teeth and radiographic criteria. Few confusions may result because of the tooth impaction, for example, caries ,periapical lesions, periodontal infection, TMJ issue, root resorption of neighboring teeth and oral cysts and tumors [9]. Third molars/ canines are the principal teeth that present as impactions $[50,45,2,3]$. Not entirely erupted third molars could warrant different manifestations and pathologies, for example, periodontitis, pain, swelling, cheek ulceration, distal caries, bone misfortune and root resorption of adjacent teeth, odontogenic growths, tumors and fundamental disease [1, $15,26,47,51,7,55]$. Many imaging techniques have been developed to assess the exact anatomic location of impacted teeth such as periapical films, dental panoramic film, cross sectional plane tomography and magnetic resonance imaging (MRI). Among this OPG and periapical radiographs are used to decide the presence of tooth impaction, angulation of impaction, anatomical complications that prevent the ordinary tooth eruption, measure of encompassing bone, connection to neighboring teeth and vital structures $[1,33,29,31,2,3]$.

\section{*Corresponding Author:}

Hemavathy O.R,

Reader, Department of Oral and Maxillofacial Surgery, Saveetha Dental College and Hospitals, Saveetha Institute Of Medical And Technical Sciences, Saveetha University, Chennai, India.

Tel: +91-9842564465

E-mail: hemavathy.sdc@saveetha.com

Received: July 23, 2020

Accepted: August 18, 2020

Published: August 29, 2020

Citation: Shruthi M, Hemavathy O.R, Murugan Thamaraiselvan. Prevalence Of Impacted Teeth In Adult Population. Int J Dentistry Oral Sci. 2020;S8:02:0018:89-93 doi: http://dx.doi.org/10.19070/2377-8075-SI02-080018

Copyright: Hemavathy $\mathbf{O}^{\circ}$ 2020. This is an open-access article distributed under the terms of the Creative Commons Attribution License, which permits unrestricted use, distribution and reproduction in any medium, provided the original author and source are credited. 
The previous studies have constantly reported that there is considerable variation in the prevalence and distribution of impacted teeth in different regions of the jaw and in different populations. $[36,54,14,60]$. There are a limited number of comprehensive studies which investigates all the impacted teeth all together and there is no data on the prevalence of impacted teeth and the most common tooth impacted in the South Indian population. Keeping this background in mind, the current study aimed to evaluate the prevalence of impacted teeth. This study fills the lacunae created by the previous study and creates awareness among the dentists and general population.

\section{Materials and Methods}

A retrospective cross-sectional study in the hospital setting of Saveetha Dental College was conducted. All the patients with the prevalence of impacted teeth within the inclusion criteria in the hospital between June 2019- March 2020 were included. The exclusion criteria were patients who do not have radiographs in the case sheets. Ethical clearance for this study sought from the Ethical Board of Saveetha Institute of Medical and Technical Sciences.

Dental records of all the patients seen within the study period were retrieved from the Dental information Archiving Software (DIAS) of Saveetha Dental College and Hospitals which contains the patients data chronologically recorded from initial visit to final visit. Cross verification was done by reviewing the photographs, radiographs to reduce the data errors available in the case sheet. The main advantage of such data collection is that data is readily available and it includes larger sample size and larger distribution of data. Data collected were entered into a spreadsheet, followed which it was subsequently analysed using the Statistical software SPSS. Frequency and percentage were calculated from the study variable. Descriptive statistics was employed to summarise the data set variable. Chi square test was done in association involving discrete data with the level of significance set at $\mathrm{p}<0.05$.

\section{Results and Discussion}

A total of 785 patients aged between $8-67$ years were treated at the hospital between the study period as mentioned above. Among these 333 were females (42.4\%) and 452 males (57.6\%). Figure 1 indicates the prevalence of impacted teeth in different age groups: age group 1-15 years (1.3\%); age group group 15-30 years $(60.8 \%)$; age group of $30-45$ years $(31.6 \%)$; age group $45-60$ years $(6.0 \%)$ and above 60 years $(0.4 \%)$. It can be inferred from the above findings that the $15-30$ years age group is the most common age group to be affected.

Figure 2 indicates the prevalence of impacted teeth among the males is $57.6 \%$ and $42.4 \%$ prevalence in females.

Figure 3 indicates that the most common tooth to get impacted is the mandibular left third molar (45.5\%) followed by the mandibu-

Figure 1. Shows distribution of impacted teeth in different age groups. X-axis shows the different age groups and Y-axis shows their frequency : $1-15$ years $(n=10) ; 15-30$ years $(n=477) ; 30-45$ years $(n=248)$; $45-60$ years $(n=47)$; age above 60 years $(n=3)$. There is a significant prevalence seen in the age group of $15-30$ years $60.8 \%(p=0.027)$. For data analysis independent sample t-test was done and for correlation chi-square test was done.

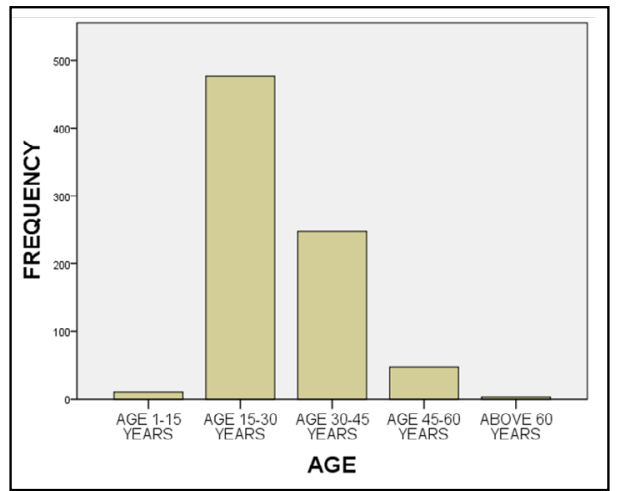

Figure 2. Shows prevalence of impacted teeth in males and females. $\mathrm{X}$-axis shows gender and $\mathrm{Y}$-axis shows their frequency: Males ( $n=333)$; Females $(n=452)$. There is a increased prevalence in males $\mathbf{5 7 . 6} \%$ however not statistically significant $(p=$ 0.752). For data analysis independent sample t-test was done and for correlation chi-square test was done.

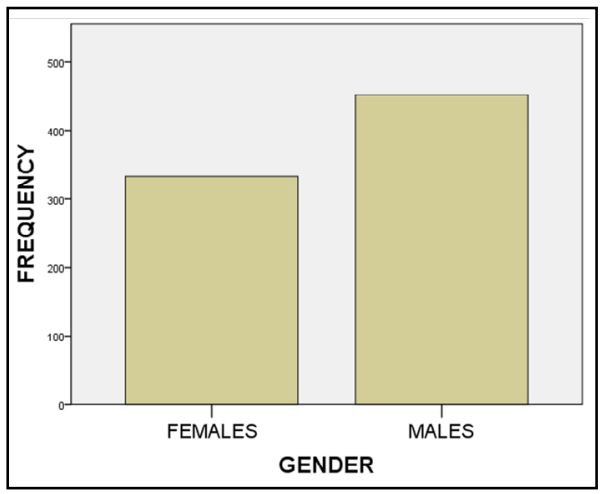


lar right third molar $(38.6 \%)$.

In figure 4, exhibiting cross tabulation between age and teeth, it can be found that the mandibular left third molar is the most common tooth to get impacted in all age groups.

In figure 5, exhibiting the cross tabulation between the gender and teeth, it can be found that the mandibular left third molar is the most common tooth to get impacted in both males and females.

This study being the first attempt in investigating the evidence of prevalence of the impacted teeth in a sample of South Indian population living in Chennai. In this study, dental records and radiographic findings were used to establish diagnostic validity.
It is based on the fact that normal body growth is essentially completed by the age of seven, the determination of all unerupted/ partially erupted teeth as impaction would be more reliable beyond this age [58].

In our study the prevalence of tooth impaction is more pronounced in males than in females, however it is not statistically significant. Several researchers have found no predilection of impaction with gender $[27,40,5,11,20]$. However some studies show opposing findings of higher frequency among females than in males $[21,41,22,48]$. The reasons for this higher frequency reported in females can be attributed to the consequence of difference between the growth of males and females. Females usually stop growing when the third molars just begin to erupt, whereas in males, the growth of the jaws continues during the time of

Figure 3. Shows prevalence of different impacted teeth. $\mathrm{X}$-axis shows the teeth no in The FDI system and Y-axis shows their frequency. There is a statistically significant prevalence seen in mandibular third molars $(38$ and 48$) 83.6 \%(p<0.0001)$. For data analysis independent sample t-test was done and for correlation chi-square test was done.

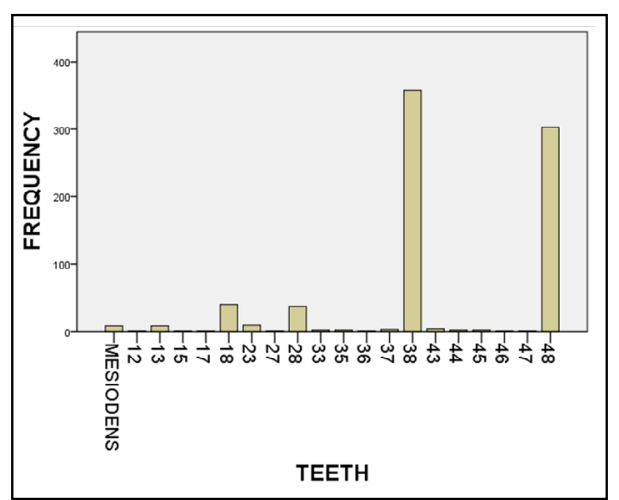

Figure 4. Bar chart showing the correlation between age and the impacted teeth prevalence $(\mathrm{p}<0.001)$. $\mathrm{X}$ - axis shows the different age groups and Y-axis shows the teeth no. For data analysis independent sample t-test was done and for correlation chi-square test was done.

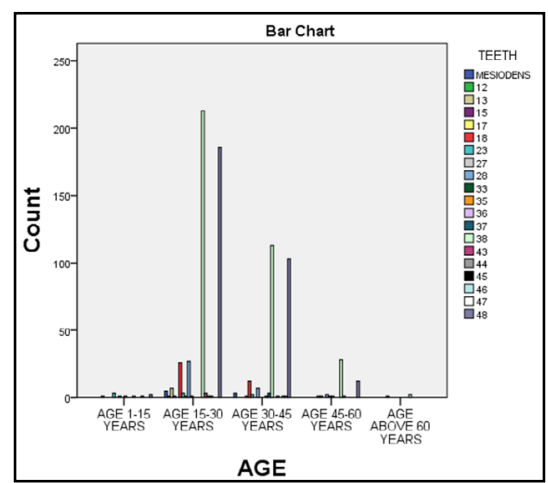

Figure 5. Bar chart showing the correlation between gender and the impacted teeth prevalence $(\mathrm{p}=0.162)$. $\mathrm{X}$ - axis shows the gender and $\mathrm{Y}$-axis shows the teeth no. For data analysis independent sample t-test was done and for correlation chi-square test was done.

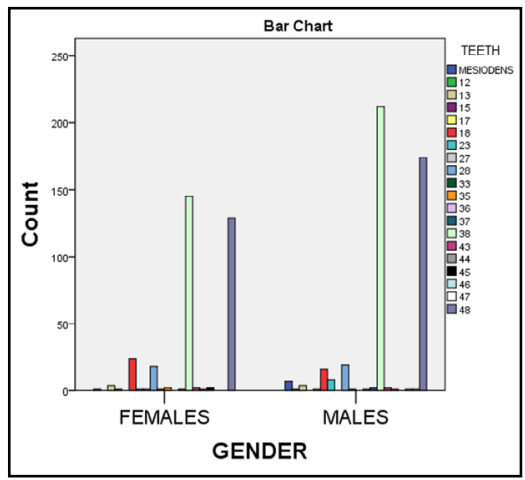


eruption of the third molars, creating more space for third molar eruption. However Haider et al., 1986 reported a higher rate of impaction among males than females which coincides with the results of our current study $[18,12]$. Nevertheless the difference in distribution of the impacted third molar between the males and females was not statistically significant. The reason for this finding may be females are more fearful about the surgical dental procedures compared to males and their awareness of the dental procedures are also relatively low compared to males [38].

In this study the most common tooth to get impacted is mandibular left third molar (45.5\%). In a statistically significant manner, the frequency of impaction of the third molars was high especially in the mandibular third molars be it in males/ females. Previous studies showed the same result [4, 9, 28, 53, 19, 25, 24]. In a study conducted by Olasoji et al., the third molar impaction was seven times more common in the urban compared to that in the rural $[42,43]$. There are many reasons for the mandibular third molar being the most common tooth impacted such as abnormal positioning of the tooth bud, lack of space in the dental arch, and mainly due to bony obstruction in the pathway of eruption or the local adjacent tooth causing hindrance $[25,30,44,49]$. But the difference in distribution of the impacted third molar between the males and females was not statistically significant in our study. The reason being females are more fearful about the surgical dental procedures compared to males.

In this study the most common tooth to get impacted is mandibular left third molar (45.5\%). The frequency of impaction of the third molars was high and statistically significant especially in the mandibular third molars be it in males/females. Previous studies showed the same result. In a study conducted by Olasoji etal.,it was found that the third molar impaction was seven times more common in the urban compared to that of the rural. There are many reasons for the mandibular third molar being the most common tooth impacted such as positioning of the tooth bud abnormally, lack of space in the dental arch, and mainly due to bony obstruction in the pathway of eruption or the local adjacent tooth causing hindrance. The third molars in the mandible are the most common tooth to get impacted in both males and females. Differential growth pattern between the genders seems to explain the higher prevalence of third molar impactions in the females. The reason for this is that the growth of the jaws in the females ceases at the time when the third molars just begin to erupt. Whereas in males the growth of jaws sustains during the time of third molar eruption, which provides adequate space for the eruption of third molar $[34,6,37]$.

In our study, prevalence of maxillary canine impaction was: maxillary right canine $(1 \%)$; maxillary left canine $(1.1 \%)$ and mandibular right canine $(0.5 \%)$; mandibular left canine $(0.3 \%)$. In a study by Shah et al. [54], 8 unerupted mandibular canines were found in 7886 individuals, and in another study 11 impacted mandibular canines were found in 5000 individuals, resulting in an incidence of $0.10 \%$ [17]. This is in line with the study conducted by Yuvuz et al, Wherein he states that the canines have a complicated eruption pattern and is one of the last teeth erupting in the dental arch. He also states that the tooth may have an unusual eruption process compared to other teeth in the oral cavity $[9,61,23,52,8$, $13,56]$. It has been concluded from this study that the premolar, central incisor and lateral incisors prevalence of impaction is uncommon which is in line with the results of other studies.
$[10,59,35]$ Very few studies have been done regarding impacted premolars. It has been concluded from the results of these studies that premolar impaction is rare, with the prevalence ranging from $2.1-2.7 \%[27,57]$.

The strength of this study was that the records of patients seen during the period of study were used; therefore there was no issue regarding declined participation from patients and in addition there was no issue regarding improper patient selection. The weakness of the study being a retrospective study, there was no possibility for direct interaction with the patients and the study relied only on the radiographic and clinical photographs and the sample size was also limited. However this study will shed light for studies in future that evaluate impacted teeth etiology and the solutions to reduce its associated adverse effects.

\section{Conclusion}

This study estimated the prevalence of impacted teeth with mandibular third molars being the most commonly impacted teeth in the oral cavity. The most common age group prevalent with impaction was the age group of 15-30 years and the males were the most prevalent ones. Continued advancements in the field of research on prevalence leads to newer treatment modalities.

\section{References}

[1]. Abbasi MM, Abbas I, Khan N, Shah SM, Hameed H, Shad S, et al. Frequency of unerupted mandibular third molar in mandibular angle fractures. Journal of Ayub Medical College Abbottabad. 2012 Mar 1;24(1):30-2.

[2]. Abhinav RP, Selvarasu K, Maheswari GU, Taltia AA. The Patterns and Etiology of Maxillofacial Trauma in South India. Ann Maxillofac Surg. 2019 Jan-Jun;9(1):114-117. PubmedPMID: 31293938.

[3]. Sweta VR, Abhinav RP, Ramesh A. Role of Virtual Reality in Pain Perception of Patients Following the Administration of Local Anesthesia. Ann Maxillofac Surg. 2019 Jan-Jun;9(1):110-113. PubmedPMID: 31293937.

[4]. Ahlqwist M, Gröndahl HG. Prevalence of impacted teeth and associated pathology in middle-aged and older Swedish women. Community Dent Oral Epidemiol. 1991 Apr;19(2):116-9. PubmedPMID: 2049918.

[5]. Aitasalo K, Lehtinen R, Oksala E. An orthopantomography study of prevalence of impacted teeth. International Journal of oral surgery. 1972 Jan $1 ; 1(3): 117-20$.

[6]. Almendros-Marqués N, Berini-Aytés L, Gay-Escoda C. Influence of lower third molar position on the incidence of preoperative complications. Oral Surgery, Oral Medicine, Oral Pathology, Oral Radiology, and Endodontology. 2006 Dec 1;102(6):725-32.

[7]. Al-wusaybie MM, Al-Ramil AM, Al-Wosaibi AM, Bukhary MT. Prevalence of Impacted Teeth and Associated Pathologies-A Radiographic Study, Al Ahsa, Saudi Arabia Population. The Egyptian Journal of Hospital Medicine. 2018 Jan 1;70(12):2130-6.

[8]. Aydin U, Yilmaz HH, Yildirim D. Incidence of canine impaction and transmigration in a patient population. DentomaxillofacRadiol. 2004 May;33(3):164-9. PubmedPMID: 15371316.

[9]. Bishara SE. Impacted maxillary canines: a review. Am J OrthodDentofacialOrthop. 1992 Feb;101(2):159-71. PubmedPMID: 1739070.

[10]. Brin I, Becker A, Zilberman Y. Resorbed lateral incisors adjacent to impacted canines have normal crown size. Am J OrthodDentofacialOrthop. 1993 Jul;104(1):60-6. PubmedPMID: 8322724.

[11]. Brown LH, Berkman S, Cohen D, Kaplan AL, Rosenberg M. A radiological study of the frequency and distribution of impacted teeth. J Dent Assoc S Afr. 1982 Sep;37(9):627-30. PubmedPMID: 6960561.

[12]. Christabel A, Anantanarayanan P, Subash P, Soh CL, Ramanathan M, Muthusekhar MR, et al. Comparison of pterygomaxillarydysjunction with tuberosity separation in isolated Le Fort I osteotomies: a prospective, multi-centre, triple-blind, randomized controlled trial. Int J Oral Maxillofac Surg. 2016 Feb;45(2):180-5. PubmedPMID: 26338075.

[13]. Cooke J, Wang HL. Canine impactions: incidence and management. Int J Periodontics Restorative Dent. 2006 Oct;26(5):483-91. PubmedPMID: 
17073358.

[14]. Eliasson S, Heimdahl A, Nordenram A. Pathological changes related to longterm impaction of third molars. A radiographic study. Int J Oral Maxillofac Surg. 1989 Aug;18(4):210-2. PubmedPMID: 2507670.

[15]. Ellamurugan, N. et al. 'Periodontitis and Rheumatoid arthritis - A Review', IOSR Journal of Dental and Medical Sciences.2013; 102-105. doi: 10.9790/0853-104102105

[16]. Gisakis IG, Palamidakis FD, Farmakis ET, Kamberos G, Kamberos S. Prevalence of impacted teeth in a Greek population. J InvestigClin Dent. 2011 May;2(2):102-9. PubmedPMID: 25426603

[17]. Grover PS, Lorton L. The incidence of unerupted permanent teeth and related clinical cases. Oral Surg Oral Med Oral Pathol. 1985 Apr;59(4):420-5. PubmedPMID: 3858781.

[18]. Haidar Z, Shalhoub SY. The incidence of impacted wisdom teeth in a Saudi community. Int J Oral Maxillofac Surg. 1986 Oct;15(5):569-71. PubmedPMID: 3097182.

[19]. Harsha S. Incidence of Mandibular Third Molar Impaction in Patients Visiting A Private Dental College. IOSR Journal of Dental and Medical Sciences. 2014;13(1):1-2.

[20]. Hattab FN, Rawashdeh MA, Fahmy MS. Impaction status of third molars in Jordanian students. Oral Surg Oral Med Oral Pathol Oral RadiolEndod. 1995 Jan;79(1):24-9. PubmedPMID: 7614155.

[21]. Hellman M. Our third molar teeth, their eruption, presence and absence. Dent. Cosmos. 1936;78:750-62.

[22]. Hugoson A, Kugelberg CF. The prevalence of third molars in a Swedish population. An epidemiological study. Community Dent Health. 1988 Jun;5(2):121-38. PubmedPMID: 3165039.

[23]. Jacobs SG. The impacted maxillary canine. Further observations on aetiology, radiographic localization, prevention/interception of impaction, and when to suspect impaction. Aust Dent J. 1996 Oct;41(5):310-6. PubmedPMID: 8961604

[24]. Vijayakumar Jain S, Muthusekhar MR, Baig MF, Senthilnathan P, Loganathan S, Abdul Wahab PU, et al. Evaluation of Three-Dimensional Changes in Pharyngeal Airway Following Isolated Lefort One Osteotomy for the Correction of Vertical Maxillary Excess: A Prospective Study. J Maxillofac Oral Surg. 2019 Mar;18(1):139-146. PubmedPMID: 30728705.

[25]. Jaiswara C, Rani A, Dhiman NK. The rarest cause of impaction of mandibular third molar - A case report. J Oral BiolCraniofac Res. 2016 Nov;6(Suppl 1):S55-S57. PubmedPMID: 27900252.

[26]. Jesudasan JS, Wahab PU, Sekhar MR. Effectiveness of $0.2 \%$ chlorhexidine gel and a eugenol-based paste on postoperative alveolar osteitis in patients having third molars extracted: a randomised controlled clinical trial. $\mathrm{Br} \mathrm{J}$ Oral Maxillofac Surg. 2015 Nov;53(9):826-30. PubmedPMID: 26188932.

[27]. Kramer RM, Williams AC. The incidence of impacted teeth. A survey at Harlem hospital. Oral Surg Oral Med Oral Pathol. 1970 Feb;29(2):237-41. PubmedPMID: 5262845.

[28]. Kruger E, Thomson WM, Konthasinghe P. Third molar outcomes from age 18 to 26: findings from a population-based New Zealand longitudinal study. Oral Surg Oral Med Oral Pathol Oral RadiolEndod. 2001 Aug;92(2):150-5. PubmedPMID: 11505260.

[29]. Kumar S. Knowledge, attitude and awareness of dental undergraduate students regarding HIV/AIDS patients ". Asian Journal of Pharmaceutical and Clinical Research. 2017:175.

[30]. Kumar S. Relationship between dental anxiety and pain experience during dental extractions. Asian Journal of Pharmaceutical and Clinical Research. 2017;10(3):458.

[31]. Kumar S. The emerging role of botulinum toxin in the treatment of orofacial disorders: Literature update. Asian Journal of Pharmaceutical and Clinical Research. 2017;10(9):21-9.

[32]. Kumar S, Rahman R. Knowledge, Awareness and practices regarding Biomedical waste management among undergraduate dental studies Asian Journal of Pharmaceutical and Clinical Research.2017; 341. doi: 10.22159/ ajpcr.2017.v10i8.19101.

[33]. Kumar S, Sneha, S. Knowledge and awareness regarding antibiotic prophylaxis for infective endocarditis among undergraduate dental students., Asian Journal of Pharmaceutical and Clinical Research.2016;154. doi: 10.22159/ ajpcr.2016.v9s2.13405.

[34]. Ma'aita J, Alwrikat A. Is the mandibular third molar a risk factor for mandibular angle fracture? Oral Surg Oral Med Oral Pathol Oral RadiolEndod. 2000 Feb;89(2):143-6. PubmedPMID: 10673648.

[35]. Marimuthu M, Andiappan M, Wahab A, Muthusekhar MR, Balakrishnan A, Shanmugam S. Canonical Wnt pathway gene expression and their clinical correlation in oral squamous cell carcinoma. Indian J Dent Res. 2018 MayJun;29(3):291-297. PubmedPMID: 29900911.

[36]. Mead SV. Incidence of impacted teeth. International Journal of Orthodontia, Oral Surgery and Radiography. 1930 Aug 1;16(8):885-90.

[37]. Meenapriya, M. et al. 'Occlusal morphology of permanent mandibular second molar', International Journal of Current Advanced Research.2017;
2703-2706. doi: 10.24327/ijcar.2017.2706.0082.

[38]. Milgrom P, Newton JT, Boyle C, Heaton LJ, Donaldson N. The effects of dental anxiety and irregular attendance on referral for dental treatment under sedation within the National Health Service in London. Community Dent Oral Epidemiol. 2010 Oct;38(5):453-9. PubmedPMID: 20545723.

[39]. Montelius GA. Impacted teeth: a comparative study of Chinese and Caucasian dentitions. Journal of Dental Research. 1932 Dec;12(6):931-8.

[40]. Morris CR, Jerman AC. Panoramic radiographic survey: a study of embedded third molars. J Oral Surg. 1971 Feb;29(2):122-5. PubmedPMID: 5279097.

[41]. Murtomaa H, Turtola L, Ylipaavalniemi P, Rytömaa I. Status of the third molars in the 20- to 21-year-old Finnish university population. J Am Coll Health. 1985 Dec;34(3):127-9. PubmedPMID: 4086717.

[42]. Olasoji HO, Odusanya SA. Comparative study of third molar impaction in rural and urban areas of South-Western Nigeria. Odontostomatol Trop. 2000 Jun;23(90):25-8. PubmedPMID: 11372160

[43]. Packiri S, Gurunathan D, Selvarasu K. Management of Paediatric Oral Ranula: A Systematic Review. J ClinDiagn Res. 2017 Sep;11(9):ZE06-ZE09. PubmedPMID: 29207849.

[44]. Patil SB, Durairaj D, Suresh Kumar G, Karthikeyan D, Pradeep D. Comparison of Extended Nasolabial Flap VersusBuccal Fat Pad Graft in the Surgical Management of Oral Submucous Fibrosis: A Prospective Pilot Study. J Maxillofac Oral Surg. 2017 Sep;16(3):312-321. PubmedPMID: 28717289.

[45]. Patil SR, Maragathavalli G, Araki K, Al-Zoubi IA, Sghaireen MG, Gudipaneni RK, et al. Three-rooted mandibular first molars in a Saudi Arabian population: A CBCT study. Pesquisabrasileiraemodontopediatria e clinicaintegrada. 2018 Aug 27;18(1):4133.

[46]. Patturaja K, Pradeep D. Awareness of Basic Dental Procedure among General Population. Research Journal of Pharmacy and Technology. 2016 Sep $1 ; 9(9): 1349$.

[47]. Singh M, Chakrabarty A. Prevalence of Impacted Teeth: Study of $500 \mathrm{~Pa}$ tients. International Journal of science and Research (IJSR). 2016;1(5):157780

[48]. Quek SL, Tay CK, Tay KH, Toh SL, Lim KC. Pattern of third molar impaction in a Singapore Chinese population: a retrospective radiographic survey. Int J Oral Maxillofac Surg. 2003 Oct;32(5):548-52. PubmedPMID: 14759117.

[49]. Rao TD, Kumar MS. Analgesic efficacy of paracetamolvs ketorolac after dental extractions. Research Journal of Pharmacy and Technology. 2018 Aug $1 ; 11(8): 3375-9$.

[50]. Ravichandran, H. et al. 'Patients attitude towards extraction of third molar- a questionnaire based study'.International Journal of Current Advanced Research.2017; 3306-3308. doi: 10.24327/ijcar.2017.3308.0257.

[51]. Rohini S, Kumar VJ. Incidence of dental caries and pericoronitis associated with impacted mandibular third molar-A radiographic study. Research Journal of Pharmacy and Technology. 2017 Apr 1;10(4):1081.

[52]. Rózsa N, Fábián G, Szádeczky B, Kaán M, Gábris K, Tarján I. Retineáltfelsómaradószemfogakelófordulásigyakoriságaés a kezeléslehetóségei 11-18 évesorthodontiaibetegeken [Prevalence of impacted permanent upper canine and its treatment in 11-18-year-old orthodontic patients]. FogorvSz. 2003 Apr;96(2):65-9. Hungarian. PubmedPMID: 12762148.

[53]. Sandhu S, Kaur T. Radiographic study of the positional changes and eruption of impacted third molars in young adults of an Asian Indian population. J Oral Maxillofac Surg. 2008 Aug;66(8):1617-24. PubmedPMID: 18634949.

[54]. Shah RM, Boyd MA, Vakil TF. Studies of permanent tooth anomalies in 7,886 Canadian individuals. II: congenitally missing, supernumerary and peg teeth. Dent J. 1978 Jun;44(6):265-8, 276. PubmedPMID: 277400

[55]. Singh R, Singh R, Singh S, Kumar A, Kunar S, Nazeer J. Assessment of Incidence and Risk Factors of Dry Socket Formation after Surgical Removal of Impacted Mandibular Third Molar. Prevalence. 2019;5:4.

[56]. S, M. P. et al. 'Study of sexual dimorphism and tooth size variation in canines in south indian population', International Journal of Current Advanced Research. 2017; 2745-2746. doi: 10.24327/ijcar.2017.2746.0095.

[57]. Thilander B, Myrberg N. The prevalence of malocclusion in Swedish schoolchildren. Scand J Dent Res. 1973;81(1):12-21. PubmedPMID: 4510864.

[58]. VargheseK. 'Why Teeth Get Impacted?',A Practical Guide to the Management of Impacted Teeth. 2010;10-10. doi: 10.5005/jp/books/11047_2.

[59]. Wedl JS, Danias S, Schmelzle R, Friedrich RE. Eruption times of permanent teeth in children and young adolescents in Athens (Greece). Clin Oral Investig. 2005 Jun;9(2):131-4.PubmedPMID: 15830243

[60]. Yamaoka M, Furusawa K, Yamamoto M. Influence of adjacent teeth on impacted third molars in the upper and lower jaws. Aust Dent J. 1995 Aug;40(4):233-5. PubmedPMID: 7575277.

[61]. Zahrani AA. Impacted cuspids in a Saudi population: prevalence, etiology and complications. Egypt Dent J. 1993 Jan;39(1):367-74. PubmedPMID: 8299537. 